\title{
High-performance liquid chromatographic assay for minocycline in human plasma and parotid saliva
}

\author{
Valerie Orti $^{\mathrm{a}, \mathrm{b}, \mathrm{c}}$, Michel Audran ${ }^{\mathrm{b}}$, Philippe Gibert ${ }^{\mathrm{c}}$, Guillaume Bougard ${ }^{\mathrm{b}}$, \\ Françoise Bressolle ${ }^{\mathrm{b}, *}$ \\ ${ }^{a}$ Laboratoire de Pharmacocinétique, Faculté de Pharmacie, 34060 Montpellier Cedex 2, France \\ ${ }^{\mathrm{b}}$ Département de Biophysique, Faculté de Pharmacie, 34060 Montpellier Cedex 2, France \\ ${ }^{\mathrm{c}}$ Faculté d'Odontologie, 34295 Montpellier Cedex 5, France
}

\begin{abstract}
A sensitive and specific high-performance liquid chromatographic (HPLC) method with UV detection was developed for the determination of minocycline in human plasma and parotid saliva samples. Samples were extracted using an Oasis ${ }^{\mathrm{TM}}$ HLB cartridge and were injected into a $\mathrm{C}_{8}$ Nucleosil column. The HPLC eluent contained acetonitrile-methanol-distilled water- $0.1 \%$ trifluoroacetic acid (25:2:72.9:0.1, v/v). Demeclocycline was used as internal standard. The assay showed linearity in the tested range of $0.1-25 \mu \mathrm{g} / \mathrm{ml}$. The limit of quantitation was $100 \mathrm{ng} / \mathrm{ml}$. Recovery from plasma or parotid saliva averaged $95 \%$. Precision expressed as $\% \mathrm{CV}$ was in the range $0.2-17 \%$ (limit of quantitation). Accuracy ranged from 93 to $111 \%$. In the two matrices studied at 20 and $4{ }^{\circ} \mathrm{C}$, rapid degradation of the drug occurred. Frozen at $-30^{\circ} \mathrm{C}$, this drug was stable for at least 2 months, the percent recovery averaged $90 \%$. The method's ability to quantify minocycline with precision, accuracy and sensitivity makes it useful in pharmacokinetic studies.
\end{abstract}

Keywords: Minocycline

\section{Introduction}

Periodontal diseases are caused by oral microorganisms growing in dental plaque, in gingival and subgingival periodontal niches [1,2]. Due to the infective nature of periodontal diseases, antimicrobial agents were used. In several studies the systemic use of tetracyclines was found to have some, although limited, beneficial effects on clinical and

\footnotetext{
*Corresponding author. Present address: Laboratoire de Pharmacocinétique, Faculté de Pharmacie, 34060 Montpellier Cedex 1, France. Tel.: +33-4-6754-8075; fax: +33-4-6779-8075.
}

microbiological parameters $[3,4]$. However, the systemic use of broad spectrum antibiotics, like tetracyclines, entails a certain risk of disturbing the commensal flora. Moreover, such administration may increase the bacterial resistance, interfere with other drugs, and have several adverse effects [5].

Therefore, local administration of antimicrobial drugs directly onto the periodontal pocket has been suggested as a means of bypassing systemic complications and targeting localised areas of periodontal destruction.

Tetracyclines are among the most widely studied antibiotics used for local delivery. In addition to its 
antimicrobial effectiveness against suspect microflora, these drugs inhibit mammalian neutrophil collagenase and in vitro bone resorption and enhance attachment of fibroblasts to root structure [6]. Tetracyclines have been incorporated into a variety of delivery systems (hollow polymer fibers, acrylic strips, collagen formulations, ointments and pastes) for insertion into periodontal pockets [7].

This work has been undertaken, to study the delivery rate of a tetracycline antibiotic, minocycline, from a resorbable collagen membrane (BIOMEND ${ }^{\circledR}$, Sulzer Medica Laboratory, Carlsbad, CA, USA) into the gingival liquid and its passage into the systemic circulation. This membrane is used in the Regeneration Tissular Guided technical and contains a collagen tendon steer. The first step of this study was to validate a method to quantify this drug in plasma and parotid saliva. Tetracyclines are polar amphoteric drugs with unfavorable chromatographic properties. They are also difficult to extract from biological fluids. Moreover, these drugs are unstable in acidic or alkaline media and are subject to photodegradation.

Several HPLC methods have been developed to quantify tetracyclines in biological fluids (plasma or serum, urine, tissues) with the aim of assaying either one main member of this group or a series of tetracycline derivatives by one chromatographic step [8-20]. A systematic comparison of chromatographic performance has been reported by White et al. [21]. These techniques are directed towards the analysis of tetracycline in general and not the specific drug minocycline. For the sample preparation prior to HPLC analysis, either liquid-liquid extraction or solid-phase extraction is used.

Today, several methods have been described to quantify minocycline in biological samples [22-26]. This drug had $\mathrm{p} K_{\mathrm{a}}$ values of 5 and 9.5 for the two amine functions (aromatic amino group in position 7 and basic group in position 4 , respectively), and 2.8 and 7.8 for the hydroxyl groups. A column-switching HPLC assay has been developed by Bompare et al. [22]. In the method developed by Bocker et al. two metabolites were isolated and identified [23]. These methods require solid-phase extraction [26], liquidliquid extraction [23,25] or simple protein precipitation [24]. However, most of the published methods either did not report assay validation or reported incomplete assay validation. A capillary zone electrophoresis has been also described to separate minocycline from its potential synthesis impureties [27].

The present paper describes an isocratic reversedphase HPLC method for the measurement of minocycline, in human plasma and parotid saliva. The procedure involved a sample clean-up by solidphase extraction; moreover the use of an internal standard allowed enhanced precision. This method was validated with respect to accuracy, precision, selectivity, and limits of quantitation and of detection according to Good Laboratory Practice Guidelines [28-30]. Moreover, stability tests under various conditions have been performed.

\section{Experimental}

\subsection{Materials and reagents}

Minocycline hydrochloride and demeclocycline (internal standard) were obtained from Sigma (St. Louis, MO, USA). Methanol and acetonitrile were purchased from Carlo Erba (Val de Reuil, France) and used without further purification. Orthophosphoric acid and trifluoroacetic acid (Sigma) were all analytical grade. $0.1 \%$ trifluoroacetic acid was then prepared by dilution in purified water (Laboratoires Fandre, Ludres, France). The $1 \mathrm{cc} / 30 \mathrm{mg}$ Oasis $^{\mathrm{TM}}$ HLB extraction cartridges were obtained from Waters Corporation (Milford, MA, USA).

The structures of minocycline and the internal standard are shown in Fig. 1. Stock solutions of minocycline $(2.5 \mathrm{mg} / \mathrm{ml})$ were prepared in the
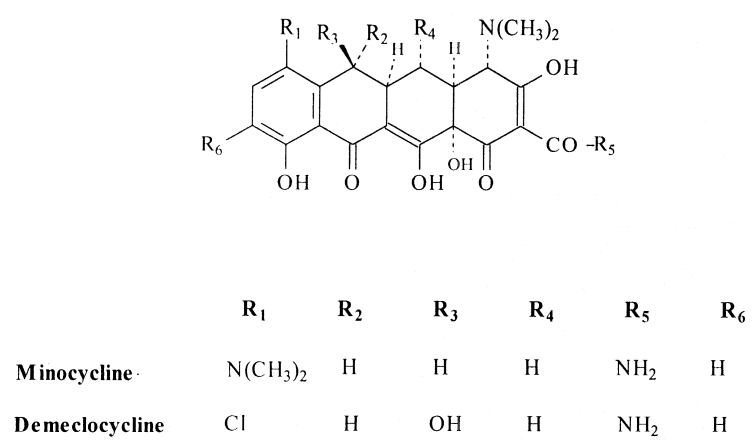

Fig. 1. Structural formulae of minocycline and internal standard. 
mobile phase. Nine working solutions ranging from 0.005 to $1.25 \mathrm{mg} / \mathrm{ml}$ were prepared in the mobile phase; they were used to prepare calibration curves and quality control (QC) samples. The internal standard solution was prepared in the mobile phase at a concentration of $1.25 \mathrm{mg} / \mathrm{ml}$.

An unextracted working solution in the mobile phase containing minocycline at a concentration of $12.5 \mu \mathrm{g} / \mathrm{ml}$ and the internal standard at a concentration of $25 \mu \mathrm{g} / \mathrm{ml}$ was prepared daily to check the resolution of the chromatographic system.

For validation of the method, human plasma (Centre de Transfusion Sanguine, Montpellier, France) and parotid saliva were obtained from pooled samples collected from healthy volunteers. Parotid saliva samples were collected by means of a modified double-lumen parotid cup. Orangeflavoured lozenges served as a reflex stimulus to induce salivation. They were stored at $-30^{\circ} \mathrm{C}$ before use.

\subsection{Equipment and chromatographic conditions}

The apparatus used for the HPLC analysis was a Hewlett-Packard multisolvent delivery system HP 1100 (Hewlett-Packard, Les Ulis, France) equipped with an autosampler, an oven and a Model HP 1100 diode array detector (Hewlett-Packard) set at wavelength of $350 \mathrm{~nm}$. Data acquisition and treatment was performed with an IBM computer using the ChemStation G2170 AA (Hewlett-Packard). Separation was done at $20^{\circ} \mathrm{C}$ using a $\mathrm{C}_{8}$ Nucleosil column ( $250 \times 4 \mathrm{~mm}$ I.D.; $5 \mu \mathrm{m}$ particle size) from Macherey Nagel (Düren, Germany). A guard column (LiChrospher $100 \mathrm{RP}-8,4 \times 4 \mathrm{~mm}$ I.D., $5 \mu \mathrm{m}$ particle size; Hewlett-Packard) was placed just before the inlet of the analytical column to reduce contamination of the analytical column. The HPLC eluent containing acetonitrile-methanol-distilled water-0.1\% trifluoroacetic acid (25:2:72.9:0.1, v/v; $\mathrm{pH}=1.76)$ was prepared daily. This mixture was filtered through a $0.45-\mu \mathrm{m}$ HV filter (Millipore, Bedford, MA, USA). Prior to use, it was degassed by vacuum then with a stream of helium during use. The isocratic separation was performed at $0.9 \mathrm{ml} / \mathrm{min}$ flow-rate, which corresponds to a pressure of about $14.8 \mathrm{MPa}$ (148 bars).

\subsection{Analytical procedure}

\subsubsection{Calibration curves and quality control (QC) samples}

Quantitation was based on the internal standard method. Twenty microliters of each working solution of minocycline were used to spike plasma and parotid saliva samples $(1 \mathrm{ml})$ in order to obtain calibration standards at concentrations of $0.1,0.5,2$, 5, 10, 12.5, 15 and $25 \mu \mathrm{g} / \mathrm{ml}$.

QC samples were prepared at the concentrations of $0.1,3.5,10.5$ and $20 \mu \mathrm{g} / \mathrm{ml}$.

Immediately after preparation, samples were acidified, as indicated below, to avoid degradation of the drug.

\subsubsection{Extraction procedure}

Preconditioning of the column was done with $1 \mathrm{ml}$ of methanol and $1 \mathrm{ml}$ of distilled water. Before solid-phase extraction, one milliliter of each sample (plasma or parotid saliva) was acidified to a final concentration of $2 \%$ phosphoric acid then $20 \mu$ of the internal standard was added. The samples were vortex-mixed for $10 \mathrm{~s}$ and loaded onto the column. The column was then rinsed with $1 \mathrm{ml}$ of $5 \%$ methanol solution. Afterwards, the column was dried by suction for $10 \mathrm{~min}$. Elution was done with $1 \mathrm{ml}$ of methanol. The eluate was evaporated at $40^{\circ} \mathrm{C}$ to dryness under nitrogen stream. The residue was dissolved in $100 \mu \mathrm{l}$ of the mobile phase; a 20- $\mu \mathrm{l}$ aliquot was injected into the column.

\subsection{Data analysis}

From recorded peak areas the ratios of the drug to internal standard were calculated. Unweighted least squares linear regression of the peak-area ratio's as a function of the theoretical concentrations was applied to each standard curve (formula: $y=a+b x$; where $x=$ concentration $(\mu \mathrm{g} / \mathrm{ml})$ and $y=$ peak area ratio). The resulting slopes and intercepts were used to obtain concentration values for that day's quality control samples and unknown samples.

The linearity of the method was statistically confirmed by comparing the slopes and the intercepts of linear calibration curves with zero, and the correlation coefficients with 1 . The back-calculated concentrations $\left(C_{\mathrm{TEST}}\right)$ were compared to the theoret- 
ical concentrations $\left(C_{\mathrm{REF}}\right)$ and the bias (or mean predictor error) was computed as follows:

$\operatorname{Bias}=\frac{1}{n} \sum_{i=1}^{i=n}\left[C_{\mathrm{TEST}(i)}-C_{\mathrm{REF}(i)}\right]$

The $95 \%$ confidence interval for bias was also computed.

\subsection{Specificity}

The specificity of the method was investigated by screening six different batches of blank human plasma and parotid saliva samples. The retention times of endogenous compounds in the matrix were compared with those of minocycline and internal standard.

\subsection{Precision and accuracy}

The precision and accuracy of the method were evaluated by performing replicate analyses of QC samples $(0.1,3.5,10.5$ and $20 \mu \mathrm{g} / \mathrm{ml})$ in plasma and parotid saliva against a calibration curve. The procedure was repeated on different days (plasma, $n=$ 13; parotid saliva, $n=7$ ) on the same spiked samples to determine inter-day repeatability. Intra-day repeatability was determined by treating spiked plasma samples in replicate the same day $(n=6)$.

Accuracy was expressed as percent recovery [mean back-calculated concentrations/theoretical concentrations] $\times 100$, while the precision was given by the inter-day and intra-day coefficients of variation.

\subsection{Determination of the limits of quantitation (LOQ) and detection (LOD)}

The LOQ was defined as the lowest drug concentration that can be determined with an accuracy of $80-120 \%$ and a precision $\leq 20 \%$ on a day-to-day basis. To determine accuracy and precision of the method at this concentration, replicate analyses of QC samples in plasma and parotid saliva were performed against a calibration curve.

The LOD was defined as the sample concentration resulting in a peak area of three times the noise level.

\subsection{Extraction recovery}

The extraction efficiency (recovery) was determined three times at three concentration levels for minocycline $(3.5,10.5$ and $20 \mu \mathrm{g} / \mathrm{ml})$ and at the concentration used during the assay for the internal standard $(25 \mu \mathrm{g} / \mathrm{ml})$. The peak areas obtained after extraction were compared with peaks resulting from standard solutions at the same concentrations.

\subsection{Stability study}

The stability of stock solutions was assessed at 20 and $4^{\circ} \mathrm{C}$.

For stability studies in the two matrices, QC samples at the concentrations of 3.5, 10.5 and 20 $\mu \mathrm{g} / \mathrm{ml}$ were used. The short-term stability was assessed at $0.25,0.5,1,2,4$, and $6 \mathrm{~h}$ at both ordinary laboratory conditions $\left(20^{\circ} \mathrm{C}\right.$ at daylight exposure) and at $4^{\circ} \mathrm{C}$. The stability of the drugs in frozen samples $\left(-30^{\circ} \mathrm{C}\right)$ was determined by periodic analysis over a period of 2 months. Samples were analyzed immediately after preparation (reference values) and after storage. Prior to their analysis, samples were brought to room temperature and vortex-mixed well. For each QC sample, three extractions were performed.

The freeze-thaw stability was also determined. QC samples were analyzed immediately after preparation and on a daily basis after repeated freezingthawing cycles at $-30^{\circ} \mathrm{C}$ on three consecutive days.

The stability of minocycline in the samples in the autosampler was inspected after $12 \mathrm{~h}$ at $20^{\circ} \mathrm{C}$.

\section{Results}

\subsection{Retention times and specificity}

Observed retention times were 4.2 and 8.2 min for minocycline and internal standard, respectively. The time intervals, where minocycline and the internal standard eluted, were free of interferences in all of the drug-free plasma and parotid saliva samples tested (Figs. 2a and 3a).

Representative chromatograms are shown in Figs. 2 and 3. 

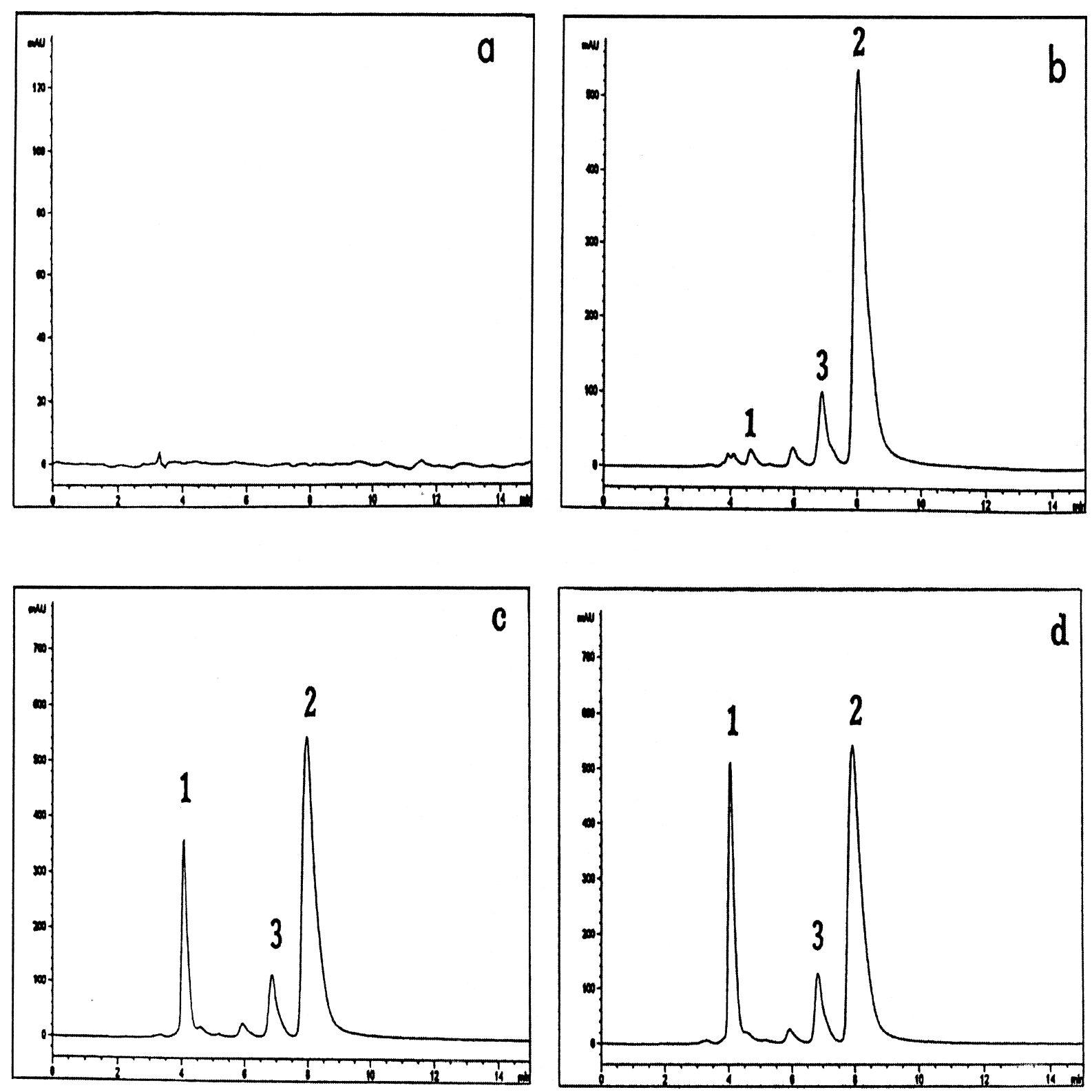

Fig. 2. Chromatograms of blank plasma (a), of plasma spiked with $0.5 \mu \mathrm{g} / \mathrm{ml}$ (b), $12.5 \mu \mathrm{g} / \mathrm{ml}$ (c), and $25 \mu \mathrm{g} / \mathrm{ml}$ of minocycline (c). For chromatographic conditions see text. Peak 1 is minocycline; peak 2 is demeclocycline; peak 3 is an additional product present in demeclocycline.

\subsection{Linearity}

Peak area ratios of minocycline over the internal standard varied linearly with concentration over the range used. The determination coefficients $\left(r^{2}\right)$ for calibration curves were equal to or better than 0.992 . Intra-day repeatability was determined for calibration curves in plasma prepared the same day $(n=6)$ using the same stock solutions. Results of unweighted least-squares linear regression analysis of these data 

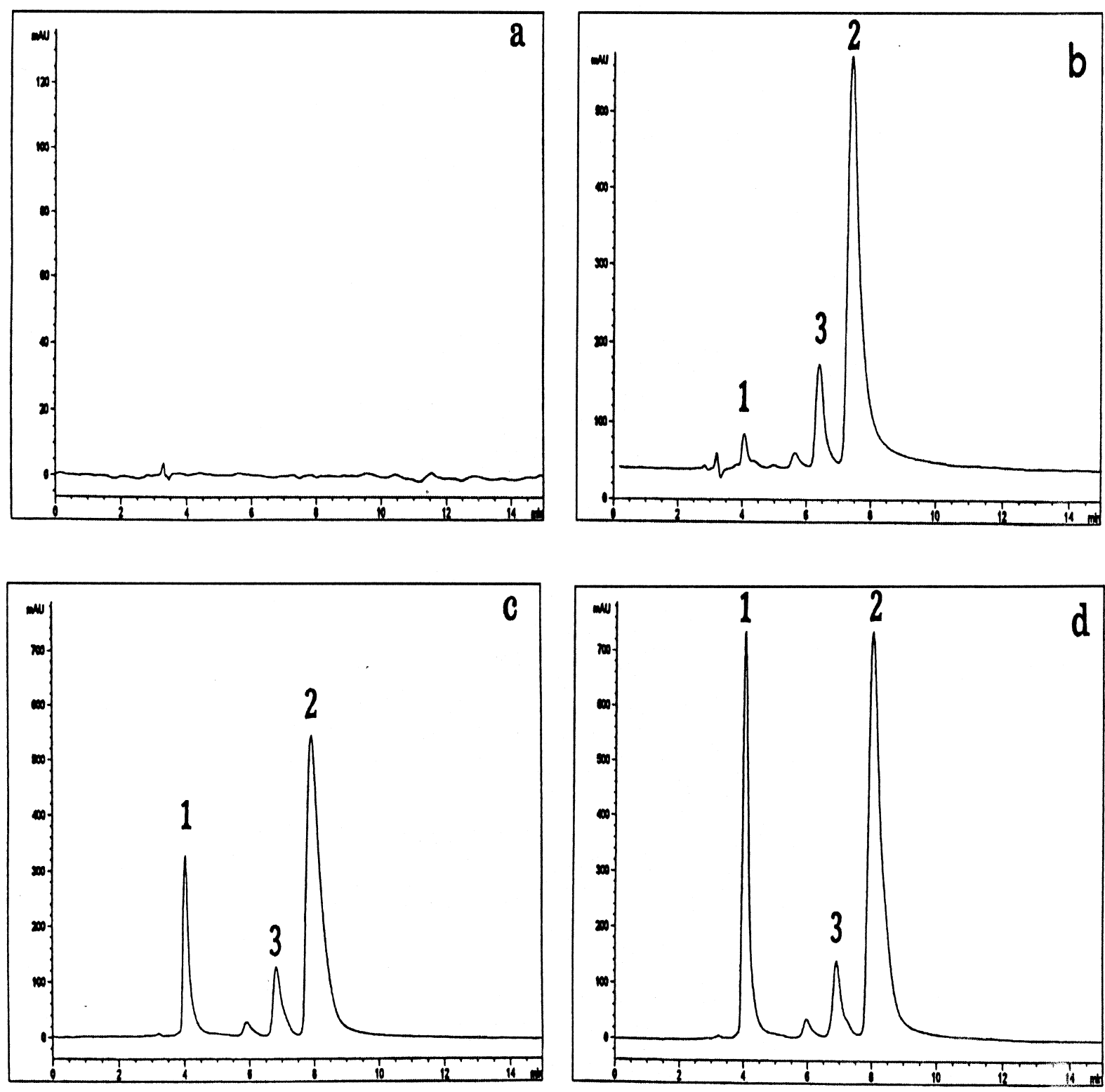

Fig. 3. Chromatograms of blank parotid saliva (a), of parotid saliva spiked with $0.5 \mu \mathrm{g} / \mathrm{ml}$ (b), $12.5 \mu \mathrm{g} / \mathrm{ml}$ (c), and $25 \mu \mathrm{g} / \mathrm{ml} \mathrm{of}$ minocycline (d). For chromatographic conditions see text. Peak 1 is minocycline; peak 2 is demeclocycline; peak 3 is an additional product present in demeclocycline.

were as follows: $r=0.996 \pm 0.0048(\mathrm{CV}=0.48 \%)$, slope $=0.051 \pm 0.0023(\mathrm{CV}=4.5 \%)$ and intercept $=$ $-0.016 \pm 0.014$. Inter-day repeatability was determined for calibration curves prepared on different days in plasma $(n=13)$ and parotid saliva $(n=7)$. Results were as follows: $r=0.997 \pm 0.0026(\mathrm{CV}=$
$0.26 \%), \quad$ slope $=0.051 \pm 0.0063 \quad(\mathrm{CV}=12 \%) \quad$ and intercept $=-0.025 \pm 0.026$ in plasma; $r=$ $0.997 \pm 0.0028 \quad(\mathrm{CV}=0.28 \%), \quad$ slope $=0.047 \pm 0.007$ $(\mathrm{CV}=14.8 \%)$ and intercept $=0.021 \pm 6.60 \times 10^{-5}$ in parotid saliva.

For each point of calibration standards, the con- 
centrations were back-calculated from the equation of the linear regression curves (experimental concentrations) and the coefficients of variation (CV\%) were computed. Inter-day and intra-day variabilities at concentration of calibration standards are presented in Table 1. A linear regression of the backcalculated concentrations versus the nominal ones provided a unit slope and an intercept equal to 0 (Student's $t$-test). The distribution of the residuals (difference between nominal and back-calculated concentrations) shows random variations, the number of positive and negative values being approximately equal. They were normally distributed and centred around zero. The bias was not statistically different from zero (Student's $t$-test) and the 95\% confidence interval included the zero value.

\subsection{Precision and accuracy}

For concentrations $(0.5-25 \mu \mathrm{g} / \mathrm{ml})$ of calibration standards, the precision around the mean value did not exceed $12 \%(0.2-12 \%)$; at the lowest concentrations $(0.1 \mu \mathrm{g} / \mathrm{ml})$, the precision was $12-17 \%$ and the accuracy $96-98 \%$ (Table 1).

The results for accuracy, intra-day, and inter-day precision are presented in Table 1. For QC samples at concentrations of $3.5,10.5$ and $20 \mu \mathrm{g} / \mathrm{ml}$, the precision ranged from 2.6 to $11 \%$. At the lowest concentration $(0.1 \mu \mathrm{g} / \mathrm{ml})$, the precision was $9-15 \%$

\subsection{Extraction recovery}

In plasma, the mean recovery $(n=9)$ averaged $99.3 \pm 3.6 \%$ for minocycline, it was $93.0 \pm 3.5 \%(n=$ $6)$ for the internal standard. In parotid saliva $(n=9)$, recoveries were $91.3 \pm 5.1$ and $99.3 \pm 0.02 \%$ for the two analytes, respectively. The extraction efficiency is not statistically different over the range of concentrations studied.

\subsection{Limit of quantitation and limit of detection}

The limit of quantitation was $0.10 \mu \mathrm{g} / \mathrm{ml}$ in plasma and parotid saliva.The limit of detection was $0.05 \mu \mathrm{g} / \mathrm{ml}$.

\subsection{Stability}

Stock solutions of minocycline and internal standard were stable for $12 \mathrm{~h}$ at $20^{\circ} \mathrm{C}$ without measurable

Table 1

Intra- and inter-day reproducibilities of the HPLC analysis ${ }^{\mathrm{a}}$

\begin{tabular}{|c|c|c|c|c|c|c|}
\hline \multirow{4}{*}{$\begin{array}{l}\text { Theoretical } \\
\text { concentration } \\
(\mu \mathrm{g} / \mathrm{ml})\end{array}$} & \multicolumn{2}{|c|}{ Intra-day reproducibility } & \multicolumn{4}{|c|}{ Inter-day reproducibility } \\
\hline & $\begin{array}{l}\text { Experimental } \\
\text { concentration } \\
(\mu \mathrm{g} / \mathrm{ml}) \\
(\text { Mean } \pm \mathrm{SD})\end{array}$ & $\begin{array}{l}\text { Mean } \\
\text { recovery } \\
(\%)\end{array}$ & $\begin{array}{l}\text { Experimental } \\
\text { concentration } \\
(\mu \mathrm{g} / \mathrm{ml}) \\
(\text { Mean } \pm \mathrm{SD})\end{array}$ & $\begin{array}{l}\text { Mean } \\
\text { recovery } \\
(\%)\end{array}$ & $\begin{array}{l}\text { Experimental } \\
\text { concentration } \\
(\mu \mathrm{g} / \mathrm{ml}) \\
(\text { Mean } \pm \mathrm{SD})\end{array}$ & $\begin{array}{l}\text { Mean } \\
\text { recovery } \\
(\%)\end{array}$ \\
\hline & \multicolumn{4}{|l|}{ Human plasma } & \multicolumn{2}{|l|}{ Parotid saliva } \\
\hline & $(n=6)$ & & $(n=13)$ & & $(n=7)$ & \\
\hline $\mathrm{QC}, 0.1$ & $0.095 \pm 0.0085$ & 95.0 & $0.098 \pm 0.0095$ & 98.0 & $0.1 \pm 0.015$ & 100.0 \\
\hline 0.1 & $0.096 \pm 0.013$ & 96.0 & $0.097 \pm 0.012$ & 97.0 & $0.098 \pm 0.017$ & 98.0 \\
\hline 0.5 & $0.48 \pm 0.041$ & 96.0 & $0.48 \pm 0.042$ & 96.0 & $0.514 \pm 0.041$ & 102.8 \\
\hline 2.0 & $2.05 \pm 0.06$ & 102.5 & $2.05 \pm 0.075$ & 102.5 & $2.03 \pm 0.235$ & 101.4 \\
\hline QC, 3.5 & $3.90 \pm 0.10$ & 111.4 & $3.52 \pm 0.40$ & 100.6 & $3.61 \pm 0.22$ & 103.1 \\
\hline 5.0 & $4.87 \pm 0.25$ & 97.4 & $4.74 \pm 0.13$ & 94.8 & $4.91 \pm 0.49$ & 98.2 \\
\hline 10.0 & $9.94 \pm 1.09$ & 99.4 & $9.89 \pm 0.16$ & 98.9 & $10.3 \pm 0.75$ & 102.8 \\
\hline QC, 10.5 & $11.1 \pm 0.47$ & 105.7 & $10.6 \pm 0.54$ & 101.0 & $10.1 \pm 0.99$ & 95.8 \\
\hline 12.5 & $13.3 \pm 0.66$ & 106.4 & $12.6 \pm 0.36$ & 100.8 & $12.8 \pm 0.88$ & 102.1 \\
\hline 15.0 & $15.1 \pm 0.21$ & 100.7 & $15.5 \pm 0.26$ & 103.3 & $14.6 \pm 1.03$ & 97.3 \\
\hline QC, 20.0 & $18.6 \pm 0.53$ & 93.0 & $20.2 \pm 0.93$ & 101.0 & $19.3 \pm 0.88$ & 96.5 \\
\hline 25.0 & $24.8 \pm 0.26$ & 99.2 & $24.8 \pm 0.055$ & 99.2 & $25.1 \pm 0.20$ & 100.4 \\
\hline
\end{tabular}

${ }^{\mathrm{a}}$ Calibration standards: $0.1,0.5,2,5,10,12.5,15,25 \mu \mathrm{g} / \mathrm{ml}$; quality control samples: $0.1,3.5,10.5,20 \mu \mathrm{g} / \mathrm{ml}$. 
Table 2

Mean percent recoveries after storage at 20 and $4^{\circ} \mathrm{C}$

\begin{tabular}{|c|c|c|c|c|c|c|}
\hline \multirow{3}{*}{$\begin{array}{l}\text { Concentration } \\
\text { added }(\mu \mathrm{g} / \mathrm{ml}) \\
n=3\end{array}$} & \multicolumn{6}{|c|}{ Percent recovery $($ mean \pm SD) } \\
\hline & \multicolumn{3}{|l|}{$20^{\circ} \mathrm{C}$} & \multicolumn{3}{|l|}{$4^{\circ} \mathrm{C}$} \\
\hline & 3.5 & 10.5 & 20 & 3.5 & 10.5 & 20 \\
\hline \multicolumn{7}{|l|}{ Human plasma } \\
\hline $15 \mathrm{~min}$ & $95.7 \pm 1.26$ & $96.8 \pm 2.17$ & $98.6 \pm 1.90$ & $93.8 \pm 1.93$ & $97.5 \pm 1.49$ & $93.8 \pm 1.49$ \\
\hline $30 \mathrm{~min}$ & $86.0 \pm 3.04$ & $93.2 \pm 3.49$ & $89.3 \pm 0.65$ & $87.7 \pm 1.08$ & $95.7 \pm 2.10$ & $90.4 \pm 3.36$ \\
\hline $1 \mathrm{~h}$ & $78.1 \pm 1.93$ & $93.3 \pm 1.44$ & $89.3 \pm 0.65$ & $81.2 \pm 1.70$ & $91.2 \pm 2.76$ & $89.6 \pm 1.98$ \\
\hline $2 \mathrm{~h}$ & $72.3 \pm 1.09$ & $86.7 \pm 2.06$ & $88.1 \pm 0.50$ & $71.1 \pm 1.03$ & $87.4 \pm 2.74$ & $88.1 \pm 1.47$ \\
\hline $4 \mathrm{~h}$ & $65.2 \pm 1.99$ & $68.8 \pm 9.86$ & $63.8 \pm 1.16$ & $67.1 \pm 1.07$ & $79.8 \pm 3.40$ & $89.6 \pm 2.10$ \\
\hline $6 \mathrm{~h}$ & $42.8 \pm 0.36$ & $59.9 \pm 1.19$ & $38.2 \pm 7.90$ & $42.4 \pm 1.08$ & $58.7 \pm 5.28$ & $63.5 \pm 12.9$ \\
\hline \multicolumn{7}{|l|}{ Parotid saliva } \\
\hline $15 \min$ & $102.6 \pm 4.54$ & $102.2 \pm 3.46$ & $104.4 \pm 1.07$ & $107.9 \pm 8.82$ & $97.4 \pm 3.63$ & $98.4 \pm 3.56$ \\
\hline $30 \mathrm{~min}$ & $96.8 \pm 8.38$ & $96.1 \pm 1.51$ & $98.8 \pm 4.22$ & $98.6 \pm 0.97$ & $98.5 \pm 0.30$ & $98.6 \pm 0.11$ \\
\hline $1 \mathrm{~h}$ & $98.6 \pm 6.98$ & $96.0 \pm 1.75$ & $97.8 \pm 6.36$ & $98.0 \pm 1.20$ & $97.0 \pm 0.35$ & $98.6 \pm 0.39$ \\
\hline $2 \mathrm{~h}$ & $83.2 \pm 2.43$ & $97.8 \pm 1.27$ & $87.9 \pm 1.74$ & $78.2 \pm 2.83$ & $87.9 \pm 3.97$ & $91.4 \pm 1.75$ \\
\hline $4 \mathrm{~h}$ & $73.0 \pm 3.15$ & $69.6 \pm 2.26$ & $86.1 \pm 1.44$ & $83.0 \pm 2.11$ & $77.0 \pm 0.05$ & $85.1 \pm 2.83$ \\
\hline $6 \mathrm{~h}$ & $54.9 \pm 0.43$ & $55.4 \pm 0.62$ & $57.8 \pm 1.55$ & $62.8 \pm 6.74$ & $62.6 \pm 2.88$ & $59.2 \pm 1.17$ \\
\hline
\end{tabular}

decomposition. At $4^{\circ} \mathrm{C}$, these solutions were stable for at least 8 days.

Stability results of plasma and saliva samples, at 20 and at $4^{\circ} \mathrm{C}$, are given in Table 2. After storage at 20 and $4^{\circ} \mathrm{C}$, a monoexponential decline in drug concentration was detected; the corresponding halflife values ranged from 6 to $8 \mathrm{~h}$ at $20^{\circ} \mathrm{C}$ and from 6 to $13.5 \mathrm{~h}$ at $4^{\circ} \mathrm{C}$.

The long-term freezer stability indicated that minocycline was stable during 2 months, the percent recovery averaged $90 \%$. Compared to the reference values, no statistical difference appeared.

Run-time stability at room temperature of processed samples after extraction was determined for each point of calibration standard. After $12 \mathrm{~h}$ no significant losses occurred.

At least two freeze-thaw cycles can be tolerated without losses higher than $10 \%$.

\section{Discussion and conclusion}

In this manuscript we described a high-performance liquid chromatographic (HPLC) method to quantify minocycline in plasma and parotid saliva. In the two matrices studied at 20 and $4^{\circ} \mathrm{C}$, rapid degradation of the drug occurred. Therefore, special attention must be paid to sample collection and handling. Assay performance was assessed both on the basis of the statistical characteristics of individual calibration lines and from the results of QC samples. Demeclocycline was regarded as an acceptable internal standard because it exhibits similar extraction properties; moreover, its use allowed enhanced precision. The limit of quantitation, $100 \mathrm{ng} / \mathrm{ml}$, was higher than that reported by Mascher $(30 \mathrm{ng} / \mathrm{ml})$ [25]; however, the limit of quantitation of the proposed analytical method can be improved by increasing the injected volume to $50 \mu \mathrm{l}$. The advantage of the solid-phase extraction used for the sample pretreatment is that the procedure can be fully automated. The present method validation results indicate that the performance characteristics of the method fulfilled the requirements for a sufficiently accurate and precise assay method to carry out pharmacokinetic studies.

\section{Acknowledgements}

The authors gratefully acknowledge support of this work by Sulzer Medica Laboratory, Carlsbad, CA, USA. 


\section{References}

[1] W.E.C. Moore, J. Periodontal. Res. 22 (1987) 335.

[2] J. Waerhaug, J. Periodontol. 49 (1978) 119.

[3] M.A. Listgarten, J. Lindhe, L.B. Helden, J. Clin. Periodontol. 5 (1978) 246.

[4] L.B. Hellden, M.A. Listgarten, J. Lindhe, J. Clin. Periodontol. 6 (1979) 222.

[5] J. Slots, T.E. Raps, J. Clin. Periodontol. 17 (1990) 479.

[6] V.P. Terranova, L.C. Franzetti, S. Hic, J. Periodont. Res. 21 (1986) 330.

[7] E. Unsal, M. Akkaya, T.F. Walsh, J. Clin. Periodontol. 21 (1994) 351.

[8] J.J. Ryan, J.A. Dupont, J. Assoc. Off. Anal. Chem. 57 (1974) 828.

[9] Y. Onji, M. Uno, K. Tanigawa, J. Assoc. Off. Anal. Chem. 67 (1984) 1135.

[10] J. MacNeil, V. Martz, G. Korsrud, C.D. Salisbury, J. AOAC Int. 79 (1996) 405.

[11] C. Bogert, A.M. Kroon, J. Pharm. Sci. 70 (1981) 186.

[12] J.P. Sharma, E.G. Perkins, R.F. Bevill, J. Chromatogr. 134 (1977) 441.

[13] J.P. Sharma, R.F. Bevill, J. Chromatogr. 166 (1978) 213.

[14] R. Böcker, C.J. Estler, Drug Res. 29 (1979) 1690.

[15] R. Böcker, C.J. Estler, Drug Res. 29 (1979) 1693.

[16] S. Ekskorg, H. Ehrsson, U. Lönroth, J. Chromatogr. 185 (1979) 583.

[17] B.G. Charles, J.J. Cole, P.J. Ravenscroft, J. Chromatogr. 222 (1981) 152.
[18] J. Hermansson, J. Chromatogr. 232 (1982) 142.

[19] F. Krämer-Horaczynska, J. Chromatogr. Sci. 29 (1991) 107.

[20] Y.F. Cheng, D.J. Philips, U. Neue, Chromatographia 44 (1997) 187.

[21] C.R. White, W.A. Moats, K.L. Kotula, J. Liq. Chromatogr. 16 (1993) 2873

[22] S. Bompadre, L. Ferrante, L. Leone, M. Montesi, L. Possati, J. Liq. Chromatogr. Rel. Technol. 20 (1997) 1257.

[23] R.H. Bocker, R. Peter, G. Machbert, W. Bauer, J. Chromatogr. 568 (1991) 363.

[24] K. Birmingham, L.M. Vaughan, C. Strange, Ther. Drug. Monit. 17 (1995) 268.

[25] H.J. Mascher, J. Chromatogr. A 812 (1998) 339.

[26] W.R. Wrightson, S.R. Myers, S. Galandiuk, J. Chromatogr. A 706 (1998) 358.

[27] Y.M. Li, A. Van Schepdael, E. Roets, J. Hoogmartens, J. Pharm. Biomed. Anal. 14 (1996) 1095.

[28] United States Pharmacopeia XXXIII, The United States Pharmacopeial Convention, Rockville, MD, USA, 1994, p. 1929.

[29] V.P. Shah, K.K. Midha, S. Dighe, I.J. McGilveray, J.P. Skelly, A. Yacobi, T. Layloff, C.T. Viswanathan, C.E. Cook, R.D. McDowall, K.A. Pittman, S. Spector, J. Pharm. Sci. 81 (1992) 309.

[30] F. Bressolle, M. Bromet-Petit, M. Audran, J. Chromatogr. B 686 (1996) 3. 